\title{
HIDDEN CURRICULUM DALAM PEMBELAJARAN PAI
}

\author{
Hikmatul Mustaghfiroh \\ COIN (Conge Institute), Jawa Tengah, Indonesia \\ hikmatulmus@yahoo.co.id
}

\begin{abstract}
Abstrak
Tulisan ini berupaya menelaah tentang kurikulum tersembunyi dalam sebuah proses pembelajaran. Dalam pembelajaran Pendidikan Agama Islam (PAI), kurikulum tersembunyi memiliki peran yang cukup signifikan dalam membentuk sikap dan karakter para siswa. Melalui penggunaan kurikulum tersembunyi, para guru dan sekolah-sekolah dapat mencapai tujuan pembelajaran PAI secara optimal. Dari penelitian yang telah dilakukan, dapat diketahui bahwa kurikulum tersembunyi merupakan kurikulum yang tidak tampak, bisa terjadi secara spontanitas, tanpa terencana dan bisa muncul dari pengalaman belajar dalam sekolah. Di samping itu, meskipun kurikulum tersembunyi tidak mempunyai sistematika yang formal dan terukur, namun sangat berperan dalam mewujudkan sebuah tujuan pembelajaran, khususnya pembelajaran PAI. Pembelajaran PAI akan dapat dicapai dengan maksimal dengan dukungan kurikulum tersembunyi melalui aktifitas siswa, baik dalam pembelajaran maupun di luar pembelajaran.
\end{abstract}

Kata kunci: kurikulum, tersembunyi, pembelajaran, PAI 


\begin{abstract}
THE HIDDEN CURRICULUM IN LEARNING PAI. This paper describes the concept of hidden curriculum in a learning process. On learning of Islamic Education (PAI), the hidden curriculum has a significant role in shaping the attitudes and character of students. Throught the use of hidden curriculum, teachers and schools will be able to achieve the learning objective of PAI optimal. Based on the research that was conducted, it can be known that hidden curriculum can happen spontaneously, and can appear from the learning experience at school. Besides, although the hidden curriculum does not have a formal and measured system, it has a significant role in creating a learning goal, especially in Islamic education learning. Islamic education learning can be achieved maximally by the support of hidden curriculum through students' activities both in and out of learning process.
\end{abstract}

Keywords: hidden curriculum, learning, Islamic Education

\title{
A. Pendahuluan
}

Pembelajaran, kurikulum memiliki peran penting dalam rangka pencapaian tujuan pembelajaran. Ibarat skenario, kurikulum menjadi dasar dalam "drama" pembelajaran yang akan berlangsung. Secara umum, kurikulum mempunyai empat komponen dasar, yaitu: tujuan, bahan, proses dan evaluasi. Keempat komponen tersebut akan membentuk sebuah siklus yang akan terus berlangsung, saling ketergantungan dari bersinergi. Pembelajaran Pendidikan Agama Islam (PAI), merupakan salah satu rumpun mata pelajaran yang bertujuan membangun karakter religius peserta didik. PAI merupakan salah satu dari 5 kelompok mata pelajaran yang menjadi standar isi dalam kurikulum KTSP yang sekarang ini berlaku. Sehingga muatan rumpun pelajaran ini, menjadi standar isi, yang "wajib” diajarkan mulai pendidikan dasar sampai menengah. Dalam standar isi, PAI masuk pada rumpun mata pelajaran agama dan akhlak. Kelompok mata pelajaran agama dan akhlak mulia dimaksudkan untuk membentuk peserta didik menjadi manusia yang beriman dan bertakwa kepada Tuhan Yang Maha Esa serta berakhlak mulia. Akhlak mulia mencakup etika, budi pekerti, atau moral sebagai perwujudan dari pendidikan agama. 
PAI memiliki tujuan yang sangat penting dalam pembentukan mental dan moral peserta didik. Meminjam taksonomi Benyamin S. Bloom, PAI mengisyaratkan terpenuhinya semua ranah pendidikan, mulai dari kognisi, psikomotor, dan afeksi. Sehingga dalam pencapaian tujuan pembelajaran PAI diperlukan strategi pembelajaran yang tepat.

Berbicara tentang pembelajaran, maka tidak bisa lepas dengan peran kurikulum. Kurikulum merupakan "cetak biru" proses pembelajaran yang berperan penting dalam pencapaian tujuan pembelajaran. Melalui kurikulum yang tepat dan relevan, pembelajaran akan mampu mengantarkan peserta didik kepada tujuan yang hendak dicapai. Tidak hanya sebagai mata pelajaran dan pengalaman belajar, kurikulum juga dipandang sebagai rencana atau program belajar. Seperti yang dikemukakan Hilda Taba "A curriculum is a plan for learning therefore, whai is know about the learning process and the development of the individual has bearing on the shaping of the curriculum" (Sanjaya, 2010: 7).

Pengertian ini merupakan pengertian kurikulum yang sebenarnya, dimana kurikulum berfungsi sebagai panduan pembelajaran. Segala sesuatu yang berkaitan dengan proses pembelajaran, yang meliputi tujuan, metode, media, materi, evaluasi dan sebagainya tertuang dalam kurikulum. Sehingga, proses pembelajaran merupakan manifestasi dari kurikulum yang telah ada.

Selain kurikulum yang disebutkan di atas, ada juga yang namanya kurikulum tersembunyi atau hidden curriculum. Secara mudah, kurikulum tersembunyi dipahami sebagai perangkat konsep yang menjadi panduan dalam pembelajaran, namun tidak secara tersurat. Hal-hal yang tidak terdokumentasikan/direncanakan/ diprogramkan atau sifatnya tidak tertulis dan hal ini sangat berpengaruh terhadap pencapaian tujuan pendidikan itu sendiri, halhal inilah yang disebut dengan kurikulum tersembunyi. Kurikulum tersembunyi merupakan aturan tidak tertulis, yang dilaksanakan oleh guru dalam mewujudkan tujuan tertentu dalam pembelajaran. Sehingga peran guru dalam pelaksanaan kurikulum tersembunyi ini sangatlah signifikan.

Jika dikaitkan dengan pembelajaran PAI, maka kurikulum 
tersembunyi ini sangatlah relevan. Pembelajaran PAI secara umum berisi tentang aspek tauhid, syariat dan akhlak. Nilai-nilai spiritual dan moralitas menjadi tekanan tersendiri dalam pembentukan perilaku peserta didik. Kurikulum tersembunyi, berfungsi sebagai kegiatan sampingan yang dilakukan guru dalam pembentukan moralitas dan spiritualitas pribadi peserta didik. Melalui kurikulum tersembunyi, guru dan pengelola sekolah atau madrasah akan mampu membekali peserta didik dengan cara yang tidak disangka-sangka.

\section{B. Pembahasan}

\section{Konsep Kurikulum Tersembunyi}

Kurikulum tersembunyi merupakan frase dari gabungan dua istilah, yakni kurikulum (curriculum) dan tersembunyi (hidden). Kurikulum secara etimologis terdiri dari kata curere yang berarti tempat berlari (gelanggang, arena) dan curir yang artinya pelari atau atlit (Maarif, 2005: 56). Sedangkan secara istilah, kurikulum dapat dipahami sebagai landasan yang digunakan pendidik untuk membimbing peserta didiknya kearah tujuan yang diinginkan melalui akumulasi sejumlah pengetahuan, keterampilan dan sikap mental.

Jika dihubungkan dengan istilah tersembunyi, maka secara umum dapat dipahami bahwa kurikulum tersebut merupakan kurikulum yang tidak terlihat, namun berperan dalam pencapaian tujuan pendidikan. Sehingga kurikulum tersembunyi dalam hal ini merupakan sesuatu yang menjadi misi tertentu yang hanya diketahui oleh seorang gurui ataupun pengelola pendidikan.

Kurikulum tersembunyi dapat dipandang sebagai tujuan yang tidak tertulis (tersembunyi). Kurikulum tersembunyi dapat diartikan sebagai segala sesuatu yang terjadi tanpa direncanakan terlebih dahulu yang dapat dimanfaatkan oleh guru untuk mencapai tujuan pembelajaran.

Pada umumnya, yang dimaksud sebagai kurikulum tersembunyi atau kurikulum terselubung adalah sebagai "hasil tersembunyi dari pendidikan dalam latar sekolah atau luar sekolah, hal ini terkait hasil yang dipelajari namun tidak secara tersurat dicantumkan sebagai tujuan” (Martin, 1983: 122). Kurikulum tersembunyi juga dapat merujuk pada penyaluran norma, nilai, dan 
kepercayaan yang disampaikan oleh guru baik dalam isi pendidikan formal dan interaksi sosial di dalam lembaga sekolah (Giroux, 1983: 100). Bukan suatu perkara yang mudah untuk mendefinisikan kurikulum tersembunyi, karena terdapatnya perbedaan antar siswa dan pengalamannya serta karena kurikulum itu selalu berubahubah seiring dengan berkembangnya pengetahuan dan keyakinan pada suatu masyarakat. Gambaran tentang kurikulum tersembunyi terwujudkan dalam gagasan bahwa lembaga sekolah tidak hanya sekedar menyebarkan pengetahuan, seperti tercantum dalam kurikulum resmi.

Kurikulum tersembunyi mengacu pada aturan-aturan atau kebiasaan yang tak tertulis, jika tidak dipahami bisa menjadikan sesuatu membingungkan dan membuat kita merasa terisolasi dan keluar dari sana (Blackwell, 2009: 24). Kurikulum tersembunyi diartikan sebagai sesuatu yang dipelajari oleh siswa di sekolah, dimana aktifitas pembelajaran direncanakan dan terorganisir melalui materi yang telah diberikan, tetapi tidak ada dalam diri mereka sendiri, dimasukkan dalam perencanaan atau terkadang dalam kesadaran mereka yang bertanggung jawab atas pengelolaan sekolah (Kelly, 2009: 7).

Kurikulum tersembunyi berfungsi dalam memperkuat ketidaksamaan sosial dengan mendidik siswa dalam berbagai persoalan dan perilaku menurut kelas dan status sosial mereka. Sama halnya seperti adanya ketidaksamaan distribusi modal budaya di masyarakat, berupa distribusi yang berhubungan dalam pengetahuan di antara para siswa (Apple, 1983: 82). Jackson menekankan tiga unsur yang harus ada dalam kurikulum tersembunyi, yaitu: dinamika kelas, interaksi antara guru dan siswa dan relasi kuasa. Kurikulum tersembunyi memperlihatkan pembelajran sikap, norma, kepercayaan, nilai dan asumsi yang sering diekspresikan sebagai aturan, ritual dan peraturan (Colin, 1991: 24).

Kurikulum tersembunyi mencakup segala bentuk pendidikan, termasuk aktivitas rekreasional dan sosial tradisional, yang dapat mengajarkan bahan-bahan pelajaran yang sebetulnya tak sengaja karena bukan berhubungan dengan sekolah tetapi dengan pengalaman belajar. 
Kurikulum tersembunyi juga dapat merujuk pada transmisi norma, nilai, dan kepercayaan yang disampaikan baik dalam isi pendidikan formal dan interaksi sosial di dalam sekolah-sekolah. Kurikulum tersembunyi ini sukar untuk didefinisikan secara eksplisit, karena berbeda-beda antar siswa dan pengalamannya serta karena kurikulum itu selalu berubah-ubah sering dengan berkembangnya pengetahuan dan keyakinan masyarakat.

Konsep kurikulum tersembunyi terekspresikan dalam gagasan bahwa sekolah melakukan lebih dari sekedar menyebarkan pengetahuan, seperti tercantum dalam kurikulum formal. Terdapat berbagai kritik tentang implikasi sosial, landasan politik, dan hasil budaya dari aktivitas pendidikan modern dibalik kurikulum tersembunyi.

Berdasarkan uraian tersebut dapat disimpulkan bahwa kurikulum tersembunyi mempunyai kriteria sebagai berikut:

1. Harapan yang tidak resmi

2. Hasil pembelajaran yang tidak disengaja

3. Pesan implisit yang timbul dari struktur sekolah

4. Dibuat oleh para siswa

5. Aspek kurikulum tersembunyi

Kurikulum tersembunyi mempunyai dua aspek, yaitu aspek relatif tetap dan aspek berubah-ubah. Aspek relatif tetap meliputi ideologi, keyakinan nilai budaya masyarakat yang mempengaruhi sekolah. Sedangkan aspek yang berubah-ubah meliputi aturan organisasi sistem sosial dan kebudayaan. Termasuk dalam aspek ini adalah pengelolaan kelas oleh guru, penyampaian dan kaidah pengajaran yang hendak di gunakan, dan sistem kenaikan kelas.

Sangatlahlah penting proses penyerapan siswa terhadap materi aktual melalui kurikulum tersembunyi, hal ini mempunyai implikasi khusus bagi figur yang menyampaikannya. Kegiatan tersebut meliputi penyampaian pelajaran sosial dan moral dengan kurikulum tersembunyi, karena karakteristik moral dan ideologi guru dan figur otoritas lainnya diterjemahkan dalam pelajaran mereka, meskipun hal ini tidak disadarinya (Kohlberg, 1983: 61).

Kurikulum tersembunyi bukan membicarakan masalah isi, 
namun lebih menekankan pada proses dari apa yang sebenarnya terjadi (Smith, 1991: 258). Sebagai contoh, ketika sekolah mengharuskan siswa untuk memakai seragam, maka apa yang sebenarnya sedang diajarkan kepada siswa? Persamaan, keserasian, atau hal lain? Ini menjadi fokus kajian dalam kurikulum tersembunyi.

\section{Konsep Pendidikan Agama Islam}

\section{a. Pengertian}

Ada banyak definisi tentang pendidikan Islam. Namun, secara umum, pendidikan Islam dapat dipahami sebagai proses untuk membentuk manusia (muslim) yang mulia, untuk mampu mewujudkan keshalehan individu dan sosial dalam rangka pencapaian tujuan risalah Islam.

Di sini pendidikan Islam tidak semata-mata menekankan pada keshalehan individu, yakni kesalehan dalam hubungan dengan Tuhan. Tetapi lebih dari itu mampu membaca, memahami dan memberikan solusi terhadap realitas sosial yang ada, sehingga misi Islam dapat terwujud di dunia ini. Hal ini sesuai dengan eksistensi keterciptaan manusia itu sendiri, yaitu di samping sebagai hamba Allah (Abdullah), juga sebagai penyelamat bumi, wakil Allah di muka bumi (khalifah Allah $f i$ al ardhi). Sedangkan definisi pendidikan agama Islam disebutkan dalam Kurikulum 2004 Standar Kompetensi Mata Pelajaran Pendidikan Agama Islam SD dan MI adalah "Pendidikan agama Islam adalah upaya sadar dan terencana dalam menyiapkanpeserta didik untuk mengenal, memahami, menghayati, meng-imani, bertakwa, berakhlak mulia, mengamalkan ajaran agama Islam dari sumber utamanya kitab suci Al-Qur'an dan Hadis, melalui kegiatan bimbingan, pengajaran, latihan, serta penggunaan pengalaman.

\section{b. Tujuan Pendidikan Agama Islam}

Tujuan adalah suasana ideal yang ingin diwujudkan. Suasana ideal dalam pendidikan Islam, tampak pada tujuan akhir yang biasanya dirumuskan secara padat dan singkat (Muhaimin, 1999: 103), seperti kedewasaan, insan kamil, manusia seutuhnya atau kebahagiaan dunia 
dan akhirat. Pencapaian suasana ideal tersebut tidak hanya merujuk pada tujuan akhir saja, Karena tujuan tersebut terlalu ideal dan belum memberikan suatu gambaran makna yang jelas, sangat normatif dan tidak operatif. Sehingga diperlukan penjabaran yang lebih rinci ke dalam bagian-bagian tertentu. Penjabaran tersebut sering disebut dengan tujuan khusus.

Pendidikan agama Islam juga bertujuan untuk meningkatkan pemahaman tentang ajaran Islam, keterampilan mempraktekkannya, dan meningkatkan pengalaman ajaran Islam itu dalam kehidupan sehari-hari. Hal ini kemudian disebut dengan keberagaman, yaitu menjadi seorang Muslim dengan interaksi keberagamaan yang penuh kesungguhan dan didasari oleh keimanan yang kuat.

Secara umum tujuan utama pendidikan Islam dapat disimpulkan untuk membangun manusia yang sesuai dengan fitrahnya, baik sebagai hamba Allah maupun sebagai khalifah. Dapat kita tegaskan bahwa selain untuk mampu mendekatkan diri kepada sang khaliq, manusia yang sempurna juga mampu berhadapan dengan realitas kehidupan serta menebarkan cinta kasih kepada seluruh alam. Output pendidikan Islam adalah mereka yang tidak hanya mempunyai kesalehan individu, tapi juga mempunyai keshalehan sosial. Keadilan, perdamaian, persamaan dan kemanusiaan yang kemudian tercermin dalam term "rahmatan li alamin" adalah bagian penting yang harus diwujudkan Pendidikan Islam.

\section{c. Dasar Pendidikan Agama Islam}

Dasar pendidikan Islam, dapat dikategorikan kedalam beberapa aspek sebagai berikut:

1) Dasar yuridis/hukum

Dasar yuridis/hukum ialah dasar-dasar pelaksanaan pendidikan agama Islam yang bersumber dari peraturan perundangundang yang secara langsung ataupun secara tidak langsung dapat dijadikan pegangan dalam melaksanakan pendidikan agama di sekolah-sekolah atau pun di madrasah.

2) Dasar Religius 
Dasar religius adalah dasar pelaksanaan pendidikan agama yang bersumber dari ajaran agama, dalam hal ini ajaran agama Islam. Berkaitan dengan dasar agama dalam pelaksanaan pendidikan agama Islam, maka dasar pertama dan utama ialah Al-Qur'an yang tidak dapat diragukan lagi kebenarannya, karena didalam Al-Qur'an sudah tercakup segala masalah hidup.

3) Dasar sosial

Dalam kehidupan sehari-hari membutuhkan bimbingan dan petunjuk yang benar, yang bernilai mutlak untuk kebahagiaan hidup di dunia dan di akhirat. Dalam kehidupan di dunia ini, manusia merupakan makhluk sosial. Ia tidak bisa hidup tanpa orang lain. Dalam kehidupan bersama secara sosial inilah di butuhkan agama sebagai pegangan hidup.

4) Muatan Pendidikan Agama Islam

Berdasarkan Peraturan Menteri Agama Nomor 2 tahun 2008 tentang Standar Kompetensi dan Standar Isi Pendidikan Agama Islam dan Bahasa Arab di Madrasah, disebutkan bahwa Pendidikan agama Islam (PAI) dalam pembelajaran di Madrasah terdiri dari 4 mata pelajaran yaitu:

\begin{tabular}{|c|c|c|c|}
\hline $\begin{array}{c}\text { Mata } \\
\text { Pelajaran }\end{array}$ & $\begin{array}{c}\text { Madrasah } \\
\text { Ibtidaiyyah (MI) }\end{array}$ & $\begin{array}{c}\text { Madrasah Tsanawiyyah } \\
\text { (MTs) }\end{array}$ & $\begin{array}{c}\text { Madrasah Aliyah } \\
\text { (MA) }\end{array}$ \\
\hline $\begin{array}{l}\text { Al Qur'an dan } \\
\text { Hadis }\end{array}$ & $\begin{array}{l}\text { a. Membaca, } \\
\text { menghafal, menulis, } \\
\text { dan memahami surat- } \\
\text { surat pendek dalam } \\
\text { Al Qur'an seperti } \\
\text { surat al-Fatihah, an- } \\
\text { Naas sampai dengan } \\
\text { surat ad-Dhuha. } \\
\text { b. Menghafal, } \\
\text { memahami arti, dan } \\
\text { mengamalkan hadis- } \\
\text { hadis pilihan tentang } \\
\text { akhlak dan amal salih. }\end{array}$ & $\begin{array}{l}\text { a. Memahami dan } \\
\text { mencintai Al-Qur'an dan } \\
\text { hadis sebagai pedoman } \\
\text { hidup umat Islam. } \\
\text { b. Meningkatkan } \\
\text { pemahaman Al-Qur'an, } \\
\text { al-Fatihah, dan surat } \\
\text { pendek pilihan melalui } \\
\text { upaya penerapan cara } \\
\text { membacanya, menangkap } \\
\text { maknanya, memahami } \\
\text { kandungan isinya, dan } \\
\text { mengaitkannya dengan } \\
\text { fenomena kehidupan. } \\
\text { c. Menghafal dan } \\
\text { memahami makna hadis- } \\
\text { hadis yang terkait dengan } \\
\text { tema isi kandungan surat } \\
\text { atau ayat sesuai dengan } \\
\text { tingkat perkembangan } \\
\text { anak. }\end{array}$ & $\begin{array}{l}\text { Memahami isi } \\
\text { pokok Al-Qur'an, } \\
\text { fungsi, dan bukti- } \\
\text { bukti kemurniannya, } \\
\text { istilah-istilah } \\
\text { hadis, fungsi hadis } \\
\text { terhadap Al-Qur'an, } \\
\text { pembagian hadis } \\
\text { ditinjau dari segi } \\
\text { kuantitas dan } \\
\text { kualitasnya, serta } \\
\text { memahami dan } \\
\text { mengamalkan } \\
\text { ayat-ayat Al-Qur'an } \\
\text { dan hadis tentang } \\
\text { manusia dan } \\
\text { tanggung jawabnya } \\
\text { di muka bumi, } \\
\text { demokrasi serta } \\
\text { pengembangan ilmu } \\
\text { pengetahuan dan } \\
\text { teknologi. }\end{array}$ \\
\hline
\end{tabular}




\begin{tabular}{|c|c|c|c|}
\hline $\begin{array}{l}\text { Akidah } \\
\text { Akhlak }\end{array}$ & \multirow{2}{*}{$\begin{array}{l}\text { Mengenal dan } \\
\text { meyakini rukun iman } \\
\text { dari iman kepada } \\
\text { Allah sampai dengan } \\
\text { iman kepada Qada } \\
\text { dan Qadar melalui } \\
\text { pembiasaan dalam } \\
\text { mengucapkan } \\
\text { kalimat-kalimat } \\
\text { thayyibah, } \\
\text { pengenalan, } \\
\text { pemahaman } \\
\text { sederhana, dan } \\
\text { penghayatan } \\
\text { terhadap rukun } \\
\text { iman dan al-asma' } \\
\text { al-husna, serta } \\
\text { pembiasaan dalam } \\
\text { pengamalan akhlak } \\
\text { terpuji dan adab } \\
\text { Islami serta menjauhi } \\
\text { akhlak tercela dalam } \\
\text { perilaku sehari-hari. }\end{array}$} & $\begin{array}{l}\text { a. Meningkatkan } \\
\text { pemahaman dan } \\
\text { keyakinan terhadap rukun } \\
\text { iman melalui pembuktian } \\
\text { dengan dalil naqli dan } \\
\text { aqli, serta pemahaman } \\
\text { dan penghayatan } \\
\text { terhadap al-asmaal-husna } \\
\text { dengan menunjukkan } \\
\text { ciri-ciri/tanda-tanda } \\
\text { seseorang dalam } \\
\text { fenomena kehidupan dan } \\
\text { pengalamannya dalam } \\
\text { kehidupan sehari-hari. }\end{array}$ & $\begin{array}{l}\text { a. Memahami } \\
\text { istilah-istilah akidah, } \\
\text { prinsip-prinsip, } \\
\text { aliran-aliran dan } \\
\text { metode peningkatan } \\
\text { kualitas akidah } \\
\text { serta meningkatkan } \\
\text { kualitas keimanan } \\
\text { melalui pemahaman } \\
\text { dan penghayatan al- } \\
\text { asma al-husna serta } \\
\text { penerapan perilaku } \\
\text { bertauhid dalam } \\
\text { kehidupan. }\end{array}$ \\
\hline & & $\begin{array}{l}\text { b.Membiasakan akhlak } \\
\text { terpuji seperti ikhlas, } \\
\text { taat, khauf, taubat, } \\
\text { tawakal, ikhtiar, sabar, } \\
\text { syukur, qana'ah, tawadhu', } \\
\text { husnuzh-zhan, tasamuh, } \\
\text { taawun, berilmu, kreatif, } \\
\text { produktif dan pergaulan } \\
\text { remaja, serta menghindari } \\
\text { akhlak tercela seperti riya, } \\
\text { nifak, ananiah, putus asa, } \\
\text { marah, tamak, takabur } \\
\text { hasad, dendam, ghibah, } \\
\text { fitnah, dan namimah. }\end{array}$ & $\begin{array}{l}\text { b. Memahami } \\
\text { istilah-istilah } \\
\text { akhlak dan tasawuf, } \\
\text { menerapkan } \\
\text { metode peningkatan } \\
\text { kualitas akhlak, } \\
\text { serta membiasakan } \\
\text { perilaku terpuji } \\
\text { dan menghindari } \\
\text { perilaku tercela. }\end{array}$ \\
\hline Fikih & $\begin{array}{l}\text { Mengenal dan } \\
\text { melaksanakan } \\
\text { hukum Islam } \\
\text { yang berkaitan } \\
\text { dengan rukun } \\
\text { Islam mulai dari } \\
\text { ketentuan dan tata } \\
\text { cara pelaksanaan } \\
\text { taharah, salat, } \\
\text { puasa, zakat, } \\
\text { sampai dengan } \\
\text { pelaksanaan } \\
\text { ibadah haji, serta } \\
\text { ketentuan tentang } \\
\text { makanan dan } \\
\text { minuman, khitan, } \\
\text { kurban, dan cara } \\
\text { pelaksanaan jual } \\
\text { beli dan pinjam } \\
\text { meminjam. }\end{array}$ & $\begin{array}{l}\text { Memahami ketentuan } \\
\text { hukum Islam yang } \\
\text { berkaitan degan } \\
\text { ibadah mahdah dan } \\
\text { muamalah serta dapat } \\
\text { mempraktikkan dengan } \\
\text { benar dalam kehidupan } \\
\text { sehari-hari. }\end{array}$ & $\begin{array}{l}\text { Memahami dan } \\
\text { menerapkan } \\
\text { sumber hukum } \\
\text { Islam dan hukum } \\
\text { taklifi, prinsip- } \\
\text { prinsip ibadah } \\
\text { dan syariat } \\
\text { dalam Islam, } \\
\text { fikih ibadah, } \\
\text { muamalah, } \\
\text { munakahat, } \\
\text { mewaris, jinayah, } \\
\text { siyasah, serta } \\
\text { dasar-dasar } \\
\text { istinbath dan } \\
\text { kaidah ushul fiqh. }\end{array}$ \\
\hline
\end{tabular}




\begin{tabular}{|c|c|c|c|}
\hline $\begin{array}{l}\text { Sejarah } \\
\text { Kebudayaan } \\
\text { Islam }\end{array}$ & $\begin{array}{l}\text { Mengenal, } \\
\text { mengidentifikasi, } \\
\text { meneladani, dan } \\
\text { mengambil ibrah } \\
\text { dari sejarah Arab } \\
\text { pra-Islam, sejarah } \\
\text { Rasulullah Saw. } \\
\text { khulafaurrasyidin, } \\
\text { serta perjuangan } \\
\text { tokoh-tokoh agama } \\
\text { Islam di daerah } \\
\text { masing-masing. }\end{array}$ & $\begin{array}{l}\text { a. Meningkatkan } \\
\text { pengenalan dan } \\
\text { kemmapuan } \\
\text { mengambil ibrah } \\
\text { terhadap peristiwa } \\
\text { penting sejarah } \\
\text { kebudayaan Islam } \\
\text { melalui perkembangan } \\
\text { masyarakat Islam pada } \\
\text { masa Nabi Muhammad } \\
\text { Saw. dan para } \\
\text { khulafaurrasyidin, Bani } \\
\text { Umaiyah, Abbasiyah, } \\
\text { Al-Ayyubiyah sampai } \\
\text { dengan perkembangan } \\
\text { Islam di Indonesia. } \\
\text { b. Mengapresiasi fakta } \\
\text { dan makna peristiwa- } \\
\text { peristiwa bersejarah } \\
\text { dan mengaitkannya } \\
\text { dengan fenomena } \\
\text { kehidupan sosial, } \\
\text { budaya, politik, } \\
\text { ekonomi, iptek dan } \\
\text { seni. } \\
\text { c. Meneladani nlai- } \\
\text { nilai dan tokoh-tokoh } \\
\text { yang berprestasi dalam } \\
\text { peristiwa bersejarah. }\end{array}$ & $\begin{array}{l}\text { a. Memahami dan } \\
\text { mengambil ibrah } \\
\text { sejarah dakwah } \\
\text { Nabi Muhammad } \\
\text { Saw. pada } \\
\text { periode Makkah } \\
\text { dan periode } \\
\text { Madinah, masalah } \\
\text { kepemimpinan } \\
\text { umat setelah } \\
\text { Rasulullah } \\
\text { Saw. wafat, } \\
\text { perkembangan } \\
\text { Islam pada abad } \\
\text { klasik/zaman } \\
\text { keemasan (650- } \\
\text { 1250 M), abad } \\
\text { pertengahan/ } \\
\text { zaman } \\
\text { kemunduran } \\
\text { (1250 M-1800 } \\
\text { M), masa } \\
\text { modern/zaman } \\
\text { kebangkitan } \\
\text { (1800- } \\
\text { sekarang), serta } \\
\text { perkembangan } \\
\text { Islam di Indonesia } \\
\text { dan di dunia }\end{array}$ \\
\hline & & & $\begin{array}{l}\text { b. Mengapresiasi } \\
\text { fakta dan makna } \\
\text { peristiwa-peristiwa } \\
\text { bersejarah dan } \\
\text { mengaitkannya } \\
\text { dengan fenomena } \\
\text { kehidupan sosial, } \\
\text { budaya, politik, } \\
\text { ekonomi, iptek dan } \\
\text { seni. }\end{array}$ \\
\hline & & & $\begin{array}{l}\text { c. Meneladani } \\
\text { tokoh-tokoh } \\
\text { Islam yang } \\
\text { berprestasi dalam } \\
\text { perkembangan } \\
\text { sejarah kebudayaan/ } \\
\text { peradaban Islam. }\end{array}$ \\
\hline
\end{tabular}

Sebagaimana dijelaskan di awal bahwa pembelajaran PAI merupakan pembelajaran yang tidak hanya menekankan pada penguasaan materi (kognitif) saja, namun lebih pada pembentukan sikap peserta didik (afeksi) dalam kehidupan sehari-hari dan sebagai bekal bagi kehidupan di masa yang akan datang. Strategi pembelajaran diperlukan tidak hanya dari kurikulum yang tertulis dan terencana, 
namun juga dari sesuatu yang tidak tertulis yang itu menjadi strategi tertentu dalam pencapaian tujuan pembelajaran yang diinginkan. Selain itu, kurikulum tersebut juga terkadang tidak terencana, muncul dengan tiba-tiba, yang kemudian dimanfaatkan untuk pencapaian tujuan pembelajaran. Pembelajaran PAI di madrasah sering kali menggunakan pola kurikulum ini dalam rangka pembentukan kepribadian Islami siswa. Sebagai contoh, pemberlakuan paket doa secara rutin tip pagi, dengan konfigurasi doa-doa tertentu secara bersama-sama, adalah mempunyai makna tersendiri dalam pencapaian tujuan pembelajaran. Dalam konteks ini, kegiatan ini bias saja dimasukkan sebagai salah satu bentuk dari kurikulum tersembunyi. Madrasah sebagai basis pendidikan Islam memiliki berbagai aktifitas keagamaan yang terkadang tidak sesuai dengan kurikulum formal yang ada. Namun hal ini-dipercaya-sangat berpengaruh terhadap pembentukan kepribadian siswa. Ini secara tidak langsung menjadi faktor pendukung bagi pencapaian pembelajaran PAI yang masuk dalam kurikulum formal.

Secara formal, Kemenag sebagai otoritas pengawas pendidikan madrasah memang tidak mengeluarkan kurikulum khusus untuk pendidikan umum madrasah, kecuali kurikulum pelengkap untuk mata pelajaran agama. Bagi madrasah yang ada di lingkungan pesantren, mempunyai peluang yang cukup besar bagi adanya hidden curriculum. Kurikulum tersembunyi ini biasanya dilaksanakan diluar jam pelajaran resmi (Azra, 2005: 158).

Kurikulum tersembunyi yang menjadi kultur sekolah lebih banyak mempengaruhi proses pembentukan kepribadian siswa daripada kurikulum formal yang ada. Berbagai macam fungsi yang ada dalam lembaga pendidikan akan tampak dari apa yang faktual dilakukan oleh individu di dalam lembaga pendidikan tersebut (Koesoema, 2006: 184), meskipun dalam hal ini tidak berarti kita meremehkan peran kurikulum formal yang ada. Karena bagaimanapun, kurikulum formal memiliki struktur tujuan, perencanaan, pelaksanaan dan sistem evaluasi yang terukur secara jelas. Fungsi kurikulum tersembunyi tersembunyi dalam hal ini adalah sebagai penunjang bagi pencapaian tujuan pembelajaran yang telah dirumuskan dalam kurikulum formal. 
Kurikulum tersembunyi merupakan salah satu karakteristik pendidikan yang secara moral-sosial relevan, yaitu proses pendidikan yang didalamnya mengandung nilai-nilai yang diperlukan dalam kehidupan nyata dalam masyarakat (Soedijarto, 2008: 339). Kurikulum tersembunyi juga menekankan perhatian bahwa dalam kelas atau sekolah, ada hubungan yang sangat terkait dengan lembaga kehidupan publik. Pengalaman sosial dalam hal ini sangat cocok dan relevan dengan keadaan siswa dalam sekolah, sehingga siswa harus ditanamkan nilai-nilai sosial yang ada di masyarakat (Lynch, 1989: 2).

Hal ini setidaknya memiliki dua alasan yang mendasar, pertama sekolah merupakan dasar kehidupan siswa. Di sini, sekolah merupakan miniatur masyarakat yang ada. Ketika di sekolah siswa ditanamkan dengan nilai-nilai sosial, maka siswa akan dilatih untuk hidup secara baik dan benar di masyarakat.

Kedua, peserta didik adalah calon pemimpin masyarakat. Dengan membekali peserta didik dengan nilai dan norma sosialagama, maka siswa nantinya ketika hidup ditengah masyarakat akan mampu menjadi pioneer bagi masyarakat yang baik. Kurikulum tersembunyi mempunyai titik signifikansinya dalam membekali peserta didik dengan sistem nilai yang Islam.

Kurikulum tersembunyi merupakan pesan-pesan yang dibawa oleh sekolah, namun tidak dikemas dalam satu pelajaran tersendiri. Misalnya tentang, patriotisme, kebaikan demokrasi, kejujuran, yang diselipkan ketika anak sedang belajar pelajaran matematika (Puline, 2007: 62).

Sebagai contoh, ketika guru menyuruh siswa untuk mengerjakan tugas secara mandiri, itu berarti ada nilai kejujuran yang sedang di ujikan kepada siswa, meskipun guru tidak menyebutkan hal itu kepada siswa. Ironisnya, sering terjadi misalnya ketika guru mengajarkan pelajaran akidah Akhlak tentang kejujuran, namun secara tidak langsung guru mengajarkan siswa untuk tidak jujur, yaitu dengan membiarkan siswa menyontek, bekerjasama dengan temannya dan sebagainya. Hal yang seperti inilah yang tidak akan kita temukan dalam kurikulum formal, sehingga peran kurikulum tersembunyi dalam hal ini sangat diperlukan. 
Implementasi kurikulum tersembunyi, diperlukan kemampuan guru dan pengelola pendidikan dalam pemahaman dan pelaksanaan kurikulum ini. Kurikulum tersembunyi bisa juga diintregasikan dengan program pengembangan diri peserta didik. Kegiatan pengembangan diri ini secara tidak terprogram dapat dilaksanakan sebagai berikut:

1. Rutin, yaitu kegiatan yang dilakukan terjadwal, seperti: doa bersama, istighosah, upacara bendera, senam, ibadah khusus keagamaan, pemeliharaan kebersihan dan kesehatan diri;

2. Spontan, adalah kegiatan yang tidak terjadwal dalam kejadian khusus seperti: pembiasaan perilaku memberi salam, saling tolong menolong, membuang sampah pada tempatya, budaya antri, mengatasi silang pendapat (pertentangan); dan

3. Keteladan, adalah kegiatan dalam bentuk perilaku seharihari seperti: tawadhu' (rendah hati), berpakaian rapi, sopan, berbahasa yang baik, rajin membaca, memuji kebaikan dan atau keberhasilan orang lain, disiplin dan sebagainya.

4. Melalui program tersebut, akan tercipta lingkungan pembelajaran dalam sekolah yang kondusif dan produktif. Dan hal ini secara langsung akan membantu tercapainya tujuan pembelajaran PAI. Inilah makna kurikulum tersembunyi, di mana bentuknya yang tidak terlihat, namun mempunyai peran yang signifikan.

\section{Simpulan}

Berdasarkan uraian di atas, dapat disajikan kesimpulan sebagai berikut:

1. Kurikulum tersembunyi merupakan kurikulum yang tidak tampak, bisa terjadi secara spontanitas, tanpa terencana dan bias muncul dari pengalaman belajar dalam sekolah.

2. Meskipun kurikulum tersembunyi tidak mempunyai sistematika yang formal dan terukur, namun sangat berperan dalam mewujudkan sebuah tujuan pembelajaran, khususnya pembelajaran PAI.

3. Pembelajaran PAI akan dapat dicapai dengan maksimal dengan dukungan kurikulum tersembunyi melalui aktifitas siswa, baik dalam pembelajaran maupun di luar pembelajaran. 


\section{Daftar Pustaka}

Apple, Michael and Nancy King. 1983. What Do Schools Teach? The Hidden Curriculum and Moral Education. Ed. Giroux, Henry and David Purpel. Berkeley, California: McCutchan Publishing Corporation.

Azra, Azumardi 2005. Dari Harvard Sampai Mekkah. Jakarta: Republika.

Blackwell, Jen. et.al. 2009. Hidden Curriculum One Calendar For Kids. USA: APC.

Giroux, Henry and Anthony Penna. 1983. Social Education in the Classroom: The Dynamics of the Hidden Curriculum. The Hidden Curriculum and Moral Education. Ed. Giroux, Henry and David Purpel. Berkeley, California: McCutchan Publishing Corporation.

Iskak, Ramli. 2003. Inilah Kurikulum Sekolah. Kuala Lumpur: PTS.

Kelly, Vic. 2009. The Curriculum: Theory and Practice. California: Thousand Oaks.

Koesoema, Doni. 2006. Pendidikan Karakter di Jaman Keblinger. Jakarta: Grasindo.

Kohlberg, Lawrence. 1983. The Moral Atmosphere of the School. The Hidden Curriculum and Moral Education. Ed. Giroux, Henry dan David Purpel. Berkeley, California: McCutchan Publishing Corporation.

Lynch, Kathleen. 1989. The Hidden Curriculum, Reproduction in Education, an Appraisal. USA: The Falmer Pres.

Maarif, Samsul. 2005. Pendidikan Pluralisme di Indonesia. Jogjakarta: Logung Pustaka.

Marsh, Colin J. 1992. Key Concept for Understanding Curriculum. USA: The Falmer Press.

Martin, Jane. 1983. What Should We Do with a Hidden Curriculum When We Find One? The Hidden Curriculum and Moral Education. Ed. Giroux, Henry, dan David Purpel. Berkeley, California: McCutchan Publishing Corporation. 
Hikmatul Mustaghfiroh

Muhaimin. 1999. Kontroversi Pemikiran Fazlur Rahman. Cirebon: Pustaka Dinamika.

Permenag Nomor 2 tahun 2008 tentang Standar Kompetensi Lulusan dan Standar Isi Pendidikan Agama Islam dan Bahasa Arab di Madrasah.

Pudjiastuti, Pauline. 2007. Sosiologi SMA kelas X. Jakarta: Grasindo.

Sanjaya, Wina. 2008. Kurikulum dan Pembelajaran. Jakarta: Kencana Prenada Media Group.

Smith, Linda. 1991. Ide-ide Filsafat dan Agama, Dulu dan Sekarang. Yogyakarta: Kanisus.

Soedijarto. 2008. Landasan dan Arah Pendidikan Nasional. Jakarta: Kompas Media Nusantara.

Tilaar, H.A.R. 2003. Kekuasaan dan Pendidikan (Suatu Tinjauan dari Perspektif Studi Kultural). Magelang: Indonesia Tera. 